\title{
The effects of riparian forest management on the freshwater environment: a literature review of best management practice
}

\author{
S. Broadmeadow and T.R. Nisbet
}

Environmental Research Branch, Forest Research, Alice Holt Lodge, Farnham GU10 4LH, UK

Email for corresponding author: samantha.broadmeadow@forestry.gsi.gov.uk

\begin{abstract}
National Forests and Water Guidelines require the establishment of riparian buffers to help protect the freshwater environment from disturbance by silvicultural operations on the adjacent land. The main functions of the riparian buffer are considered to be sediment removal and erosion control, protection of water quality, moderation of shade and water temperature, maintenance of habitat structural diversity and ecological integrity, and improvement of landscape quality. This review paper assesses how these functions are affected by the design and management of the riparian forest zone, with a focus on the width of the buffer, the structure of the vegetation and species choice. It is not possible to specify a definitive riparian buffer width that will protect the freshwater environment from every potential threat. Forestry agencies usually recommend widths between 10 and $30 \mathrm{~m}$. Buffer widths towards the lower end of this scale tend to protect the physical and chemical characteristics of a stream, while the maintenance of ecological integrity requires widths at the upper end. In terms of structure and species, the benefits are greatest where the riparian buffer replicates native riparian woodland with an open canopy of mixed species of varied age class. The optimum level of shade is difficult to quantify but limited work suggests that a good balance is achieved where around $50 \%$ of the stream surface is open to sunlight and the remainder covered by dappled shade. Within the management of riparian woodland there is a need to consider a stream's sensitivity and intrinsic value. Some sites will benefit from active intervention such as thinning, coppicing or pollarding, while others will be favoured by a hands-off approach. Long-term continuity of management is important to ensure that the potential benefits to the freshwater environment are realised.
\end{abstract}

Keywords: riparian woodland, riparian buffer, woodland management, freshwater environment, water quality

\section{Introduction}

Land use can exert a particularly strong influence on the freshwater environment, with both agricultural and forestry practices having the potential to degrade water quality and physical habitats within streams. The large-scale conifer afforestation of upland areas in the north and west of Britain has altered the ecology of many major rivers, which now either rise within or mainly drain extensive forest plantations (Clenaghan et al., 1998; Maitland et al., 1990; and Ormerod et al., 1986). These early plantations were established when environmental concerns were not given the priority that they receive today. Trees were densely planted close to streams so that they grew up to cast heavy shade over the water and bank sides. Consequently, the herbaceous riparian vegetation often disappeared, exposing the riverbanks to erosion and reducing the biodiversity and productivity of the stream.

These first rotation forests are now being felled and restocked, providing an important opportunity to improve the forest structure and to create more diverse forests of higher landscape and wildlife value. An essential element of the redesign is to open up stream sides to more light and restore the naturally protective functions of the riparian zone. This is to be achieved by the establishment of a riparian buffer, which is designed to protect the freshwater environment from disturbance by silvicultural operations on the adjacent land.

The influence of the riparian buffer on the stream will depend upon its width, structure, species composition and the management of the vegetation. A cover of riparian woodland is viewed by many as being beneficial to the freshwater environment (SNW, 1996). Tree roots and marginal herbaceous vegetation stabilise stream banks and regulate the flow of sediment and nutrients. This helps to protect water quality and prevent siltation, as well as maintaining a deep channel suitable for fish. Tree and shrub 
canopies also moderate the riparian microclimate and the primary productivity of the stream, and through the contribution of leaf litter and coarse woody debris enhance the quality of wildlife habitat. Riparian trees form an important food source for adult fish both directly through the input of terrestrial invertebrates that fall from the canopy and indirectly via leaf-litter, which forms the basis of the food chain. The presence of coarse woody debris within the stream creates diversity in channel form and water depth and increases the retentiveness and productivity of the stream.

It is important to recognise, however, that riparian woodland can also have negative impacts on the water environment. The main concern revolves around excessive shade and the effect of this on the productivity of salmonid fisheries. Excessive shade can result in bare stream banks leading to increased erosion, the siltation of spawning gravels, wider and shallower streams and the loss of bank side cover. At the same time, lower water temperatures will reduce in-stream productivity, while the exclusion of nonwoodland invertebrates and too much leaf litter may favour coarse fish to the detriment of salmonids. The presence of large amounts of coarse woody debris can also cause problems. Debris dams may become sealed by sediment and finer woody material, restricting fish passage. In addition, coarse woody debris can deflect flows, leading to the formation of new, wider or multiple channels, with consequent effects on fish movement, navigation and access.

The forest riparian zone in much of North America and Europe typically retains a cover of natural woodland. In Britain however, this was historically cleared together with the adjacent land for open pasture and then subsequently planted with conifers during the major programme of upland afforestation in the 1940-1980s (Forestry Commission, 2002). As these crops are harvested there is the potential to restore a cover of native riparian woodland, although this is opposed by some fishery groups. They believe that the riparian zone should be left open following conifer clearance to maximise water temperatures and thus salmonid productivity, especially in the colder parts of the country. In response, the Forestry Commission's (FC) Forests and Water Guidelines (FC, 2003) try to balance the range of positive and negative interactions of riparian woodland by recommending that about half the length of the water channel is kept open to sunlight with the remainder covered by dappled shade. However, this advice is largely based on subjective assessments and the effects of varying the design and management of the riparian buffer on the freshwater environment remains imprecise. The purpose of this review is, therefore, to draw together the international literature on best practice for riparian forestry. In particular, the paper considers how the width of the buffer, the structure of the vegetation, the mix of species and woodland management affect each of the main functions of the riparian zone. These are considered to be sediment removal and erosion control; protection of water quality; moderation of shade and water temperature; maintenance of habitat structural diversity and ecological integrity; and improvement of landscape quality.

\section{Buffer width}

The purpose of the riparian buffer is generally to protect both the aquatic and riparian zones from disturbance. It therefore follows that its dimensions will be influenced strongly by the natural extent of these zones, as dictated by site topography. Buffers that are too narrow are likely to provide inadequate protection, while if they are too wide the area of productive crop and thus income is reduced. This would complicate the management of forest operations by creating fragmented stands and would dissuade forest landowners and managers from complying with best management practices (Bren, 1995). A balance thus needs to be struck between the benefits and cost of increasing the buffer width, based on a detailed consideration of the main functions of the riparian buffer in relation to the sensitivity of a given site.

Erosion control has been highlighted as one of the main functions of a riparian buffer. The buffer acts as a barrier to the soil disturbance caused by silvicultural operations on the adjacent land. It can also serve as an effective filter for removing sediments in drainage waters. Riparian vegetation helps to impede surface run-off by encouraging sheet flow rather than channelled flow, so increasing the rate of infiltration and the deposition of suspended material. Rooting of vegetation also improves the soil structure and binds erodible soil, thereby stabilising stream banks (Castelle et al., 1994).

In Britain, protecting streams from sedimentation resulting from cultivation and drainage operations is one of the principal functions of riparian buffers, and is the criterion used to define their size. The Forests and Water Guidelines recommend average buffer widths on each side of a watercourse of: $5 \mathrm{~m}$ for channels up to $1 \mathrm{~m}$ wide; $10 \mathrm{~m}$ for channels 1-2 m wide; and $20 \mathrm{~m}$ for channels $>2 \mathrm{~m}$ wide. Although the Guidelines note that the risk of sediment movement will depend on the method of cultivation, erodibility of the soil, slope and the catchment area of individual drains, the only advice is to double the width of the buffer on very erodible soils.

Relatively few studies have attempted to quantify the ability of a riparian buffer to retain sediments in run-off. The main UK study was by Swift and Norton (1993), who 
demonstrated that buffers of coarse grass and heather were effective at reducing run-off flow velocities and increasing the deposition of suspended solids released after pre-planting ploughing and drainage operations in southern Scotland. Effectiveness depended on slope, soil type, physical structure of the vegetation, particle size and run-off velocity. They estimated that $50 \%$ attenuation in the suspended sediment load was achieved across a buffer 60-70 m wide on mineral soils, when the vegetation was growing actively. However, this efficiency was likely to be greatly reduced on slopes above $4^{\circ}$ due to the vegetation becoming flattened by surface run-off during high rainfall, particularly in winter. A narrower buffer was found to be effective for less erodible soils, such as peat.

More research on the effectiveness of riparian buffers for controlling sediment losses has been conducted overseas but mainly involving riparian forest rather than grassland buffers. The buffer widths recommended by Swift and Norton (1993) correspond well with the Russian Ministry of Reclamation and Water Management, who require water protection zones of 55-100 $\mathrm{m}$ for forest land of $>3^{\circ}$ slope (Mel'chanov, 1988). These widths were derived from studies investigating the width of riparian woodland required to convert surface flow to ground water during snowmelt, so protecting streams from potential contamination by sediment and pesticides.

Wong and McCuen (1982) derived an equation to define effective buffer widths based upon sediment particle size, slope, surface roughness and run-off flow rate in the coastal forests of Maryland, USA. The relationship was non-linear. For example, on a $2^{\circ}$ slope, the buffer width would have to be doubled from 30 to $60 \mathrm{~m}$ to increase sediment removal from 90 to $95 \%$. Lynch et al. (1985) report that an unfelled buffer of $30 \mathrm{~m}$ was effective at controlling non-point source pollution from logging operations in Pennsylvania, USA, removing approximately $80 \%$ of the suspended solids, as well as reducing nutrient levels in storm water to well below drinking-water standards. Moring (1982) also found that a $30 \mathrm{~m}$ wide unfelled buffer protected gravel beds from sedimentation caused by logging so that salmon eggs and alevins developed normally. Curry et al. (2002) report that a $20 \mathrm{~m}$ wide uncut buffer was successful in reducing the magnitude of sedimentation following a major storm event in a Newfoundland trout stream subject to clear felling

Another important function of the riparian zone is the protection of the chemical quality of stream water by the retention of nutrients, pesticides and other pollutants in surface run-off or ground water. Their removal is achieved by a variety of processes, including the enhanced deposition of particulate matter, plant uptake and soil microbial processes.
Most work to date has focused on the use of riparian woodland buffers in lowland regions to reduce the entry of agricultural pollutants into streams and rivers (Phillips, 1989; Haycock et al., 1993; Hubbard and Lowrance, 1994). Many workers have reported such buffers to be effective at removing nitrate from drainage water flowing either through or across the riparian zone. For example, Pinay et al. (1993) found that a $30 \mathrm{~m}$ riparian buffer removed nitrate to less than detection levels in the shallow ground water flowing through a riparian forest by the River Garonne in France. Haycock and Pinay (1993) similarly demonstrated that 99\% of the nitrate in waters draining from arable fields across a poplar floodplain in England during the winter was retained within the first $5 \mathrm{~m}$ of the buffer area. Others have reported the importance of soil denitrification for removing nitrogen in the anaerobic soils that typify the riparian zone. For example, Hubbard and Lowrance (1994) noted that a $7 \mathrm{~m}$ forested buffer was effective at removing nitrate through plant uptake and denitrification, while $\mathrm{Xu}$ et al. (1992) found that soil nitrate concentrations fell from $764 \mathrm{mg}$ $\mathrm{N} \mathrm{kg}^{-1}$ soil to $0.5 \mathrm{mg} \mathrm{N} \mathrm{kg}^{-1}$ soil within the first $10 \mathrm{~m}$ of the buffer area.

Riparian buffers also have a role in reducing nutrient losses to streams in upland forests. Retention of phosphate is particularly important to prevent nutrient enrichment and algal problems in standing waters after aerial applications of rock phosphate fertiliser to young crops. Swift and Norton (1993) demonstrated that a $50 \mathrm{~m}$ wide buffer was effective at reducing total phosphorus concentrations in drainage waters from $10 \mathrm{mg} \mathrm{P}^{-1}$ to $<1 \mathrm{mg} \mathrm{P} \mathrm{l}^{-1}$, as long as flow rates were not high. At the end of the crop rotation, a riparian buffer can help to reduce losses of nutrients after forest harvesting (FC, 1998). Research has shown that clear felling can result in a marked release of nitrate on some sites, with a greater risk of increased stream water acidity and aluminium concentrations in acid-sensitive areas (Reynolds et al., 1995; Neal and Reynolds, 1998). The main cause of the accelerated nitrate leaching is disruption of the nitrogen cycle, particularly the absence of plant uptake on felled, bare sites. It has been proposed that the establishment of a riparian woodland buffer with dense herbaceous ground cover would help to remove nitrate from drainage waters, reducing leaching losses and minimising the risk of any short-term acidification effects from future felling. This is potentially important in areas of the country considered nitrogen saturated (CEH, 2001).

Riparian buffers have a specific function in reducing the risk of pesticide treatments on the adjacent land contaminating stream waters. Protection is achieved by prohibiting pesticide use in the buffer and by the ability of riparian soils and vegetation to retain any pesticides in 
Table 1. The sensitivity of three fish species to stream temperature according to Crisp (1996).

\begin{tabular}{lccc}
\hline & Salmo salar & Salmo trutta & Thymallus thymallus \\
\hline Temperature range for $>50 \%$ egg survival to hatch $\left({ }^{\circ} \mathrm{C}\right)$ & $0-12$ & $1-11$ & $4-8$ \\
$\begin{array}{l}\text { Optimal temperature range for adult fish }\left({ }^{\circ} \mathrm{C}\right) \text { (over which feeding occurs } \\
\text { and there are no signs of abnormal behaviour) }\end{array}$ & $6-20$ & $4-19$ & $4-18$ \\
\hline
\end{tabular}

drainage waters, especially those associated with sediment (Lowrance et al., 1985).

Another important aspect is the effect of the width of the riparian buffer on the level of shade over the water's surface and thus on water temperature (Barlow and Harrison, 1999). Invertebrates and fish are cold-blooded (poikilotherms) and thus much of their behaviour and life cycle is influenced or controlled by water temperature (Table 1). In the moderate oceanic climate of Britain and Ireland, too much shade limits the primary productivity of a stream (Proctor, 1986) and the development of fish and invertebrates (Weatherley and Ormerod, 1990), while too little can result in excessive temperatures for fish spawning and survival (O'Grady, 1993). Consequently, upland conifer streams have often been reported as being less productive than their moorland counterparts (FFL, 1990; Weatherley and Ormerod, 1990; Smith, 1980). For example, the experimental bank side clearance of conifers from a $10 \mathrm{~m}$ wide zone along the River Tywi in Wales reduced the mean daily water temperature in the winter by $0.5-1{ }^{\circ} \mathrm{C}$ but increased it by $0.5-1^{\circ} \mathrm{C}$ in the spring/summer. Growth models predicted that these changes would be sufficient to increase the rate of egg development and the growth of mayflies, stone flies and brown trout. After one year of simulated growth, brown trout in the cleared forest stream attained $97 \%$ of the mass of trout in the moorland stream, compared with $78 \%$ in the uncleared forested stream. The increase in fish size in the cleared stream was attributable to the higher stream temperatures accelerating fish egg development and growth, as well as increasing invertebrate productivity and thus food supply (Weatherley and Ormerod, 1990).

Quigley (1981) presents a simple stream surface shade model that allows the length and orientation of the shadow cast by the riparian vegetation to be estimated for any given site and time. Table 2 compares the length of shade that would be cast by a $25 \mathrm{~m}$ tall tree growing in southern England and northern Scotland between the spring and autumn equinoxes. As expected, the longest shadows are at sunrise and sunset, and increase with latitude in response to the lower sun angle. Shadows on south facing slopes are shorter than those on north facing slopes, an effect that is enhanced as the slope becomes steeper. The data demonstrate that a $25 \mathrm{~m}$ tall forest crop on a gentle slope would need a minimal buffer width of 13-14 $\mathrm{m}$ in the south and 16-19 $\mathrm{m}$ in the north for a stream to receive any direct sunlight. Quigley's model can also be used to investigate how changes in the width and vegetation structure of the riparian zone affect stream shade. Table 3 shows that the level of shading is most sensitive to buffer width in the south and vegetation height in the north. Shade increases in direct proportion to crown density and is least sensitive to crown diameter.

To derive a relationship between the dimensions of the

Table 2. Effects of latitude, slope and aspect on the shadow cast by a $25 \mathrm{~m}$ tall tree (calculated using the stream surface shade model of Quigley (1981)).

\begin{tabular}{|c|c|c|c|c|c|c|c|c|c|}
\hline \multirow{2}{*}{$\begin{array}{l}\text { Latitude, } \\
\text { Location }\end{array}$} & \multirow[t]{2}{*}{ Date } & \multirow[t]{2}{*}{ Time of Day } & \multicolumn{7}{|c|}{ Shadow length $(\mathrm{m})$ for different slope angles $\left(^{\circ}\right)$ and aspects } \\
\hline & & & $0^{\circ}$ & $7^{\circ} \mathrm{N}$ & $7^{\circ} \mathrm{S}$ & $7^{\circ} \mathrm{E}$ & $7^{\circ} \mathrm{W}$ & $21^{\circ} \mathrm{N}$ & $21^{\circ} \mathrm{S}$ \\
\hline \multirow{4}{*}{$\begin{array}{l}51.5^{\circ} \mathrm{N} \\
\text { London }\end{array}$} & \multirow[t]{2}{*}{$21^{\text {st }}$ March } & Noon & 31 & 37 & 27 & 31 & 31 & 65 & 23 \\
\hline & & $9 \mathrm{am}, 3 \mathrm{pm}$ & 51 & 60 & 44 & 43,64 & 64,43 & 101 & 35 \\
\hline & \multirow[t]{2}{*}{$21^{\text {st }}$ June } & Noon & 13 & 14 & 13 & 13 & 13 & 18 & 12 \\
\hline & & $9 \mathrm{am}, 3 \mathrm{pm}$ & 24 & 26 & 23 & 22,28 & 28,22 & 29 & 22 \\
\hline \multirow{4}{*}{$\begin{array}{l}57.5^{\circ} \mathrm{N} \\
\text { Inverness }\end{array}$} & \multirow[t]{2}{*}{$21^{\text {st }}$ March } & Noon & 39 & 49 & 33 & 39 & 39 & 106 & 26 \\
\hline & & $9 \mathrm{am}, 3 \mathrm{pm}$ & 61 & 76 & 51 & 50,79 & 79,50 & 158 & 39 \\
\hline & \multirow[t]{2}{*}{$21^{\text {st }}$ June } & Noon & 17 & 19 & 16 & 17 & 17 & 24 & 14 \\
\hline & & $9 \mathrm{am}, 3 \mathrm{pm}$ & 27 & 28 & 25 & 24,30 & 30,24 & 33 & 23 \\
\hline
\end{tabular}


Table 3. Sensitivity of stream surface shade to changes in riparian woodland structure, assuming a stream orientation of $30^{\circ}$ (i.e. NE/SW) and a flat site (calculated using the stream surface shade model of Quigley (1981)).

\begin{tabular}{|c|c|c|c|c|c|c|c|}
\hline \multirow[t]{2}{*}{ Characteristic } & \multirow[t]{2}{*}{ Initial } & \multirow[t]{2}{*}{ Final } & \multirow[t]{2}{*}{$\%$ Change } & \multicolumn{2}{|c|}{$\begin{array}{l}\text { Daily mean shade value } \\
\text { London } 51.5^{\circ} \mathrm{N} \\
\text { Initial value }=39.5^{b}\end{array}$} & \multicolumn{2}{|c|}{$\begin{array}{l}\text { Inverness } 57.5^{\circ} \mathrm{N} \\
\text { Initial value }=40.6^{b}\end{array}$} \\
\hline & & & & Final $^{c}$ & $\%$ Change & Final $^{c}$ & $\%$ Change \\
\hline Overstory top height (m) & 20 & 24 & +20 & 48.3 & +22.3 & 53.3 & +31.3 \\
\hline Crown diameter $(\mathrm{m})$ & 8 & 9.6 & +20 & 42.4 & +7.3 & 46.2 & +13.8 \\
\hline Canopy density (\%) & 80 & 96 & +20 & 47.4 & +20.0 & 48.7 & +20.0 \\
\hline $\begin{array}{l}\text { Distance between vegetation } \\
\text { and stream bank }(\mathrm{m})\end{array}$ & 15 & 18 & +20 & 29.1 & -26.3 & 35.6 & -12.3 \\
\hline
\end{tabular}

riparian buffer and stream water temperature in Japan, Nakamura and Dokai (1989) related tree height, crown diameter and stream width to stream temperature; they estimated that removal of riparian woodland would increase the daily maximum water temperature by up to $4^{\circ} \mathrm{C}$, depending on stream width. Similarly, Barton et al. (1985), from studies in the USA, derived an empirical regression model which accounted for $90 \%$ of the variation in the relationship between maximum water temperature of 10 trout streams in southern Ontario, Canada and riparian buffer length and width (Fig. 1). From the graph, it can be seen that a $1 \mathrm{~km}$ length woodland buffer would need to be $140 \mathrm{~m}$ wide and a $2 \mathrm{~km}$ length buffer only $50 \mathrm{~m}$ wide to ensure a maximum weekly temperature of less than $22^{\circ} \mathrm{C}$, the temperature threshold for sustainable trout populations in Ontario.

Other workers have investigated the width of riparian buffer needed to ensure that the natural temperature regime remained unaffected by harvesting operations within forested catchments. Curry et al. (2002) report that a $20 \mathrm{~m}$ wide uncut buffer protected the thermal regime of brook trout spawning gravels in a Newfoundland stream subject to clear felling. Brazier and Brown (1973) found that a $24 \mathrm{~m}$ wide forest buffer provided sufficient shade for small streams adjacent to a clear fell, while Lynch et al. (1985) determined that a $30 \mathrm{~m}$ buffer kept the water temperature within $1{ }^{\circ} \mathrm{C}$ of the former mean temperature. Zwieniecki and Newton (1999) report that $12 \mathrm{~m}$ wide screens of shrubs and trees left on the southern bank of three streams were sufficient to maintain the average maximum temperature and diurnal patterns preceding the harvest. Broderson (1973) determined that a $15 \mathrm{~m}$ wide buffer was effective in steeply sloping terrain. Riparian buffers that are at least $30 \mathrm{~m}$ wide

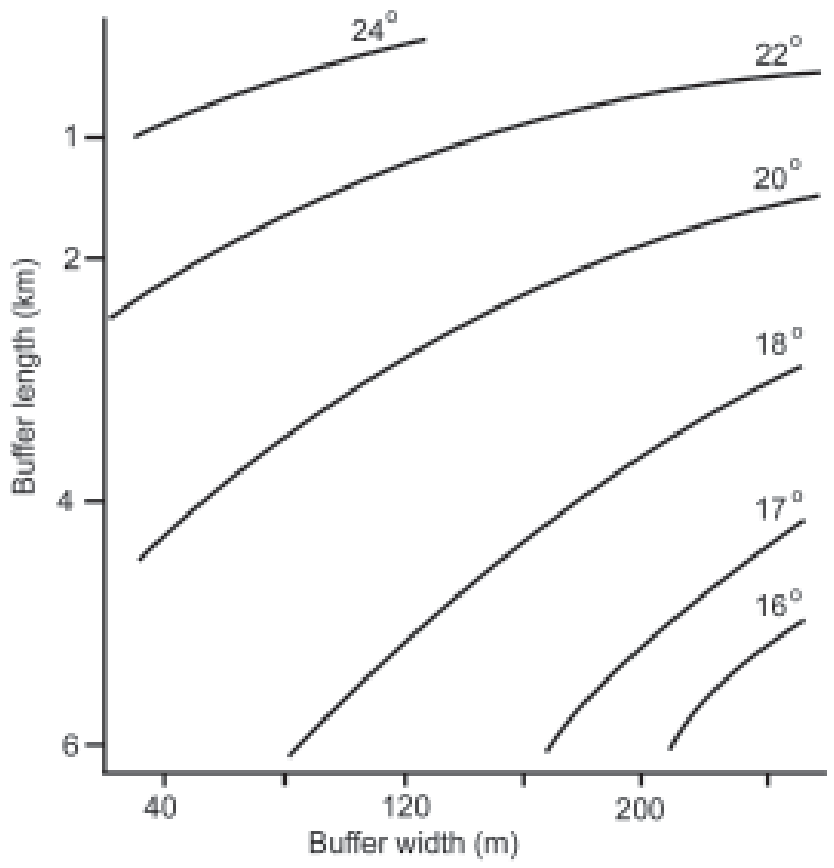

Fig. 1. The predicted trimean weekly maximum temperature $\left({ }^{\circ} \mathrm{C}\right)$ of ten southern Ontario trout streams with woodland buffer zones of varying length and width. Where $y=29.9-5.8 x_{1}^{0.33}-15.4 x_{2} ; y=$ trimean weekly maximum temperature, $x_{1}=$ length $(\mathrm{km})$ of buffer strip upstream of site and $x_{2}=$ buffer width $(\mathrm{km})$, redrawn from Barton et al. (1985).

have generally been found to provide the same level of shading and maintain a similar temperature regime to that of an old-growth forest (Beschta et al., 1987).

In terms of habitat structural diversity and ecological integrity, most studies have been conducted in the USA to inform State forestry agencies involved in setting minimum widths for riparian forest buffers to protect the aquatic 
ecosystem from the effects of forest harvesting (Lynch et al., 1985). Erman et al. (1977) found that $30 \mathrm{~m}$ wide unfelled riparian woodland was sufficient to maintain benthic invertebrate populations in Californian streams adjacent to logging activity. In contrast, O'Laughlin and Belt (1995) advise that the width of the riparian buffer should equal the maximal tree height of the crop $(\approx 52 \mathrm{~m})$ to ensure a continued supply of coarse woody debris to the stream, matching that of the old-growth forest. However, Oelbermann and Gordon (2000) reported that litter traps suspended above the surface of a stream flowing through a 50-100 m wide poplar and alder riparian zone within pasture land, received only $53 \%$ of the quantity of litter collected above a stream in a natural floodplain woodland. In the UK, Cowan (1998) surveyed the invertebrate abundance and diversity of two conifer plantations in northern England. One stream had an unplanted 10-50 m wide riparian buffer extending $3.8 \mathrm{~km}$ along its length, which had become established with a mix of birch scrub and wetland vegetation. The invertebrate community of this stream was as diverse and abundant as nearby streams with riparian zones of moorland or native woodland. Rundle et al. (1992) and Ormerod et al. (1993) found that 5-20 m wide buffers effectively protected stream habitat structure and macro invertebrate communities from the potentially detrimental effects of forest operations on stream discharge and water temperature. Castelle et al. (1994) concluded that the minimum buffer width to protect streams and wetlands should be 15 to $30 \mathrm{~m}$ in most circumstances. The physical and chemical characteristics of a stream may be protected by buffer widths towards the lower end of this scale, while maintenance of ecological integrity is likely to require widths at the upper end. Far greater buffer widths are often recommend for sites of high ecological value (Fig. 2).

In the USA a summary of 49 States' forest riparian guidelines by Blinn and Kilgore (2001) shows that most States recommend widths below the above mentioned range. Just less than two-thirds specify widths of 7.5-15 m, while some $25 \%$ set widths in the range $15-30 \mathrm{~m}$. Swedish guidelines (Skogsstyrelsen, 2000) set widths of 10-30 m depending on site sensitivity, while the Irish Forestry and Water Quality Guidelines (Forest Service, 2000) recommend minimum widths of 10-20 m for moderate and very steeply sloping ground, and 15-25 m for highly erodible soils. Castelle and Johnson (2000) noted that buffer widths in the range of 5-30 m typically provided at least 50\% and often $75 \%$ or greater effectiveness at protecting the various stream functions associated with undisturbed forest streams.

Landscape quality is also influenced by the width of the riparian buffer. The design of open space within a forest, of which the riparian buffer is an important element, is significant in controlling both the unity and naturalness of the woodland landscape. Maitland et al. (1990) suggest varying the width of the buffer on either bank of a stream, depending on its orientation. They recommend buffers of similar width on either bank where a stream flows northsouth, but where it flows east-west, two-thirds of the buffer area should lie on the south of the stream. This allows

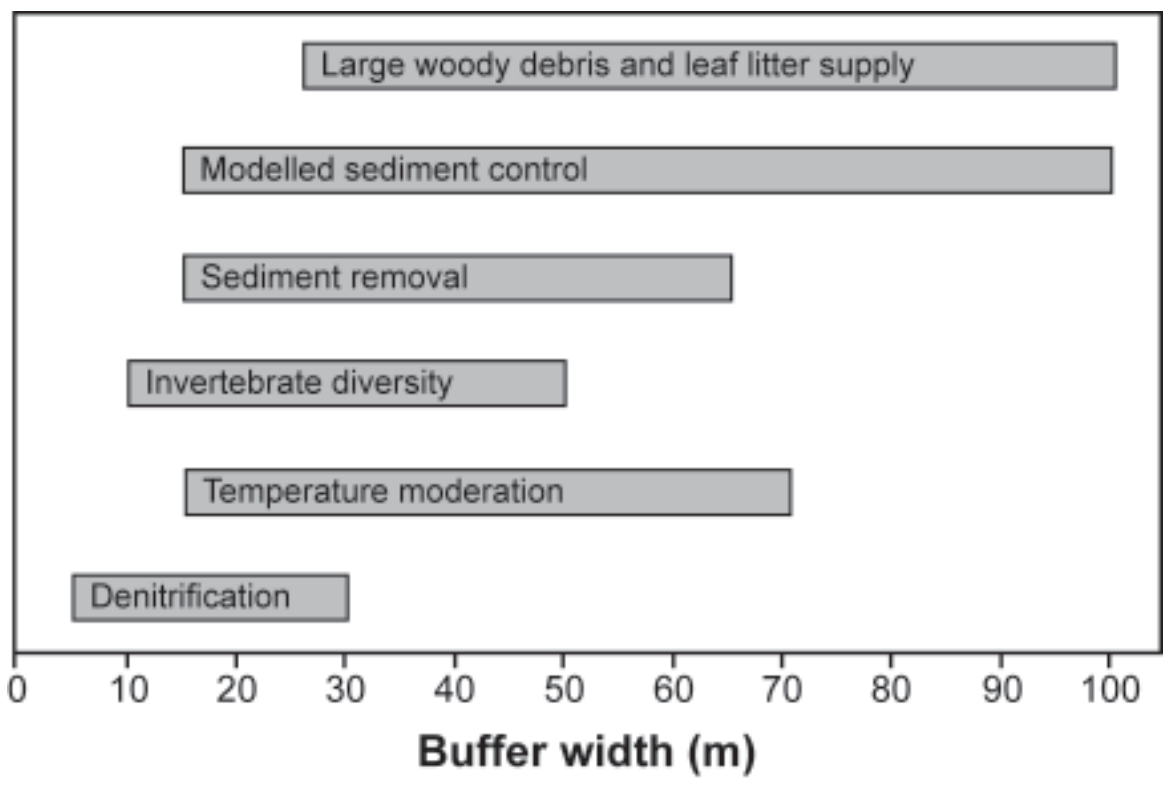

Fig. 2. The range of riparian woodland buffer widths reported in the literature as being required for the adequate performance of several specific buffer functions. 
maximum sunlight to reach the stream and introduces more variety within the landscape. The UK Forest Landscape Design Guidelines (FC, 1994a) recommend that the buffer area should be irregular in width and reflect the scale of visual and ecological diversity within the landscape.

\section{Buffer structure}

Forestry guidelines and specifications for riparian buffers generally adopt a zonal approach to the structure of the vegetation. Most identify two or three distinct zones and detail the preferred dimensions and structure according to the authors' concerns and situation (FC, 2003; Lynch et al., 1985; FDACS, 1993; Sweeney, 1993; ONF, 1999). The Forests and Water Guidelines define a buffer area as consisting of three zones: the aquatic zone, the riparian zone and the adjacent land (FC, 2003). The ecological and physical functions of the vegetation within each of these are summarised in Table 4.

The composition of the vegetation cover strongly influences the ability of the buffer to retain sediments in drainage waters. Woodland assists sediment control by helping to slow water flows, so encouraging sedimentation. This is due to the well structured and generally drier nature of woodland soils, which receive and absorb surface runoff from the adjacent land. Additionally, woody debris and surface roots help to create a network of dams and pools that act as sediment traps.

The presence of ground vegetation is also important, an intact sward of grass being very effective at trapping and fixing sediment deposits. A good cover of marginal and aquatic vegetation helps to protect stream banks from erosion, thereby maintaining deeper stream channels. Consequently, an open tree canopy that provides sufficient light to maintain a vigorous understory and ground cover is often regarded as the most effective land cover for retaining sediment and minimising bank erosion.

This view is supported by the work of Phillips (1989), who used a detention-time model to evaluate the pollutioncontrol effectiveness of 19 riparian forests in North Carolina, USA. The model predicted that a buffer with a continuous tree canopy and sparse undergrowth would have to be $28 \%$ wider than one with dense undergrowth to be as effective at controlling sediment losses. Swift and Norton (1993) also found that a buffer was more effective at retaining sediments and nutrients when the ground vegetation was growing vigorously and remained upright during the dormant season. They stressed the importance of adjusting the width of the riparian buffer in vulnerable areas to account for variation in slope and the density of the ground vegetation.

Others have noted that there can be a significant delay in establishing suitable riparian vegetation after the clearance of dense forest from stream banks, particularly where felling brash is left on site. Ormerod et al. (1993) surveyed 66 upland conifer and moorland streams in Scotland and Wales, 11 of which had conifer crops cleared from stream banks to create 5-20 m wide riparian buffers. The cleared streams were found to have retained some of the physical characteristics of the forest streams 7 years after the trees had been felled. Typically, the streambed was stony and the

Table 4. The functions of vegetation within the three contiguous zones in a riparan buffer with respect to the aquatic ecosystem (adapted from Ilhardt et al.., 2000).

\begin{tabular}{|c|c|c|c|}
\hline Zone & Location & Component & Function \\
\hline \multirow[t]{2}{*}{$\begin{array}{l}\text { Aquatic } \\
\text { Zone }\end{array}$} & \multirow[t]{2}{*}{ The stream channel } & Coarse woody debris & $\begin{array}{l}\text { Control water and sediment flow, creating diverse mosaic of pools and } \\
\text { riffles. Wildlife habitat. }\end{array}$ \\
\hline & & Aquatic plants & Retain sediment, nutrients and leaf litter. Wildlife habitat. \\
\hline \multirow[t]{3}{*}{$\begin{array}{l}\text { Riparian } \\
\text { Zone }\end{array}$} & \multirow[t]{2}{*}{ Stream banks } & Roots & $\begin{array}{l}\text { Reduce bank erosion and provide shelter. Nutrient uptake from drainage } \\
\text { water }\end{array}$ \\
\hline & & $\begin{array}{l}\text { Marginal herbaceous } \\
\text { vegetation }\end{array}$ & $\begin{array}{l}\text { Reduce bank erosion and retain sediment. Source of leaf litter and } \\
\text { terrestrial invertebrates. Wildlife habitat. }\end{array}$ \\
\hline & $\begin{array}{l}\text { Above the high } \\
\text { water mark }\end{array}$ & $\begin{array}{l}\text { Canopy and stems } \\
\text { of riparian trees } \\
\text { and shrubs }\end{array}$ & $\begin{array}{l}\text { Shade controls water temperature and primary productivity of the } \\
\text { stream. Source of leaf litter, coarse woody debris and terrestrial } \\
\text { invertebrates. Nutrient uptake and retention. Wildlife habitat. }\end{array}$ \\
\hline $\begin{array}{l}\text { Adjacent } \\
\text { Land }\end{array}$ & Adjoining slopes & $\begin{array}{l}\text { Woodland and } \\
\text { open vegetation }\end{array}$ & $\begin{array}{l}\text { Barrier to forestry operations, thus protecting the riparian } \\
\text { and aquatic zones from disturbance. Retain nutrients and sediment in } \\
\text { surface run-off. Source of leaf litter. Wildlife habitat. }\end{array}$ \\
\hline
\end{tabular}


banks had a high proportion of hard features with little aquatic or marginal vegetation.

The age structure of a woodland buffer also influences its ability to control sediment movement. The presence of old and mature trees is especially valuable in contributing large woody debris to the forest floor and streams. Large woody debris dams reduce the rate of water flow and, thus, the transport of sediment by increasing channel roughness and reducing energy gradients (Montgomery, 1997). They are also very important in pool formation and in determining the in-stream storage capacity for bed load (Swift and Norton, 1993).

The structure of the buffer vegetation has less of an effect on water chemistry, with the main interaction concerning the retention of nutrients. Primary productivity regulates the nutrient retention capacity and is greater for an earlymid successional stage plant community compared with a mature climax one (Haycock et al., 1993). Consequently, the recommended vegetation structure for maintaining nutrient uptake is a matrix of different aged woodland communities.

The microbial flora and fauna also have an important part to play in nutrient retention, especially in regulating denitrification. This is a key removal pathway for nitrate and tends to be greatest during winter when soils are wettest and vegetation uptake is at a minimum. The process is aided by the availability in woodland soils of easily mineralisable sources of organic carbon from leaf litter, root decay and root exudates. Haycock and Pinay (1993) found that a poplar-grass riparian buffer strip was more effective in retaining nitrate in ground water than a grass ley. The poplargrass mix retained $99 \%$ of the nitrate compared with $84 \%$ for the grass meadow.

Vegetation structure has a direct effect on the level of shade cast over the water's surface and thus on water temperature. Guidelines usually seek to achieve a compromise between the extremes of excessive and no shade. For example, the FC Forests and Water Guidelines recommend that $50 \%$ of the water surface should be under dappled shade (FC, 2003) and this specification falls within the range of desirable light regimes suggested by other authors. A summary of State guidelines in the USA by Blinn and Kilgore (2001) noted that almost half of those specifying a proportion of trees to be left in the riparian zone following harvesting, recommended leaving $50 \%$ of the original canopy or basal area intact.

An intricate mosaic of open ground, occasional large old trees, scrub thicket and closed canopy woodland is often the favoured structure for riparian buffers. This creates habitat diversity and, thus, conservation value, as well as a range of other environmental benefits. Over-mature trees are especially important in providing dead wood and woody debris to the stream system. O'Connor (1992) noted that $25 \%$ of the macro invertebrate species identified in a stream survey in northern Victoria, Australia, were associated with submerged red gum wood. Submerged logs and brash dams cause local flow diversions that modify streambed morphology and alter channel width, stream depth, flow rate and streambed substrate size, creating a more complex mosaic of wildlife habitats. Deep-water pools are an important habitat for mature fish and form upstream and downstream of active debris dams. They act as refuges for aquatic fauna during periods of low flow, and as dead-zones of reduced flow velocity during spates (Linsted and Gurnell, 1998).

Areas of open ground and light shade are important for maintaining a good cover of aquatic and marginal vegetation, which has an important influence on the benthic invertebrate population. For example, O'Grady (1993) reported that the cover of aquatic vegetation was reduced by $60 \%$ in stream sections flowing under a complete conifer canopy compared to those measured in adjacent open streams. Lester et al. (1994) showed that where the riparian willow canopy in a New Zealand stream reduced the incident illumination by up to $80 \%$, the macro invertebrate abundance and biomass was just half that recorded in open streams. However, Glova and Sagar (1994) studied the effects of different levels of shade on three New Zealand streams and showed that the biomass and diversity of benthic invertebrates, as well as the abundance and biomass of brown trout, tended to be higher in moderately shaded stream sections compared with those with dense willow shading or open areas. The moderately shaded stream sections had a $40 \%$ shrub canopy cover with $\sim 50 \%$ of the streambed covered by filamentous green algae.

In Britain, Smith (1980) reported a greater abundance of invertebrates in sections of a Scottish stream that were bordered by open moorland or meadow compared with those flowing through dense conifer forest completely lacking in ground vegetation. The grass canopy in the meadow and moorland reduced incident illumination by about $10 \%$ and maintained approximately $55 \%$ of the channel bed covered with moss. The stream was later resurveyed after parts of the forest had been felled and restocked, leaving some sections with an unplanted riparian buffer (Campbell, 2002). Clearance resulted in the reappearance of marginal and riparian herbaceous vegetation and a gradual increase in invertebrate abundance over a subsequent seven-year period.

A survey of 18 streams in the upper catchment of the River Tywi in Wales (Rutt et al., 1989; Weatherley et al., 1989) revealed three distinct macro invertebrate communities related to the marginal habitat and substratum characteristics. 
Moorland streams had more herbaceous vegetation and supported specialist marginal taxa that were absent in the streams in the conifer plantation, which tended to have bare and eroded banks. A similar pattern emerged from a larger survey of the macro invertebrate population in 66 upland streams across Scotland and Wales (Ormerod et al., 1993). Buffers established at the time of conifer planting were effective in supporting diverse macro invertebrate communities typical of the natural riparian vegetation. Conifer forest streams with moorland buffers had similar communities to moorland streams, while those with broadleaved buffers closely resembled streams in seminatural woodland. Streams where the buffer had been cleared of conifer forest retrospectively had lower macro invertebrate species diversity than those with established semi-natural riparian vegetation (Fig. 3). Grass/moorland streams supported the greatest abundance and diversity of grazer, collector and predator species. Shredder and filter species were, however, more abundant and diverse in broadleaf woodland streams (Rundle et al., 1992).
Weatherley et al. (1993) found that some species were specific in their habitat preferences. Dytiscid and hydrophilid beetles, and leptophlebiid mayflies, favoured the soft margins of grass/moorland streams and forest streams with moorland buffers. Caddis flies and helodid beetles preferred hard margins such as tree roots, and were found only in streams draining semi-natural woodland or those with a broadleaf buffer.

The vegetation structure of the riparian zone also has a large influence on the habitat value for birds and mammals. Many bird and several bat species feed, roost and nest in riparian broadleaf trees. The abundant invertebrate fauna of broadleaf woodland is good foraging habitat for opportunistic feeding bird species, such as the Grey Wagtail (Ormerod and Tyler, 1991). Riparian woodland is the natural habitat for the otter and water vole, which are two important and threatened mammal species. Otters prefer to create their holts within the exposed roots of mature riparian trees, but also use rock falls (Scotland) and bramble and blackthorn thickets (west Wales). They feed and rest during the day in
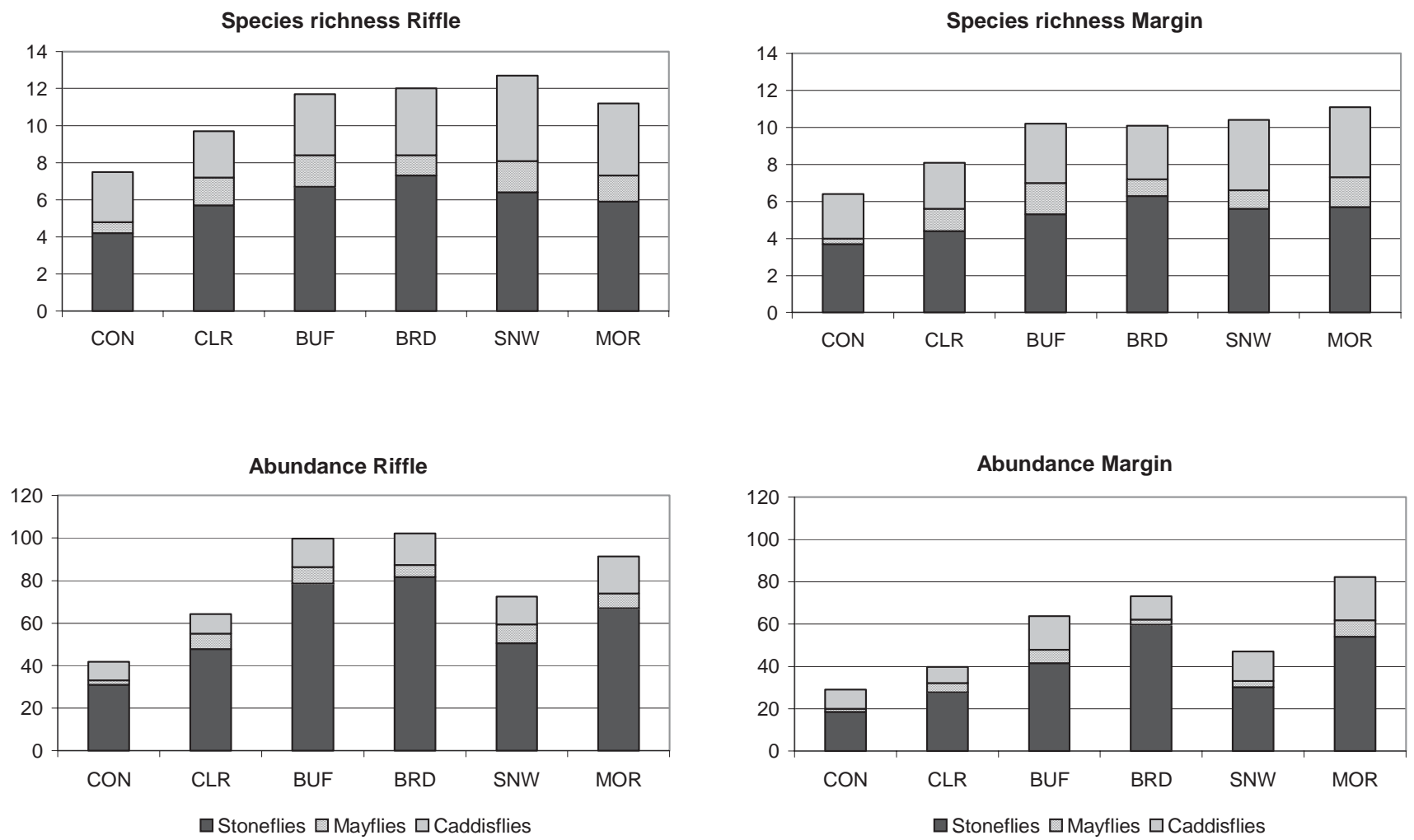

Fig. 3. The influence of riparian management on the macro invertebrate communities of upland streams draining plantation forests in Scotland and Wales (from Ormerod et al. (1993)). Where: CON are streams in conifer forests planted up to and including the stream banks; CLR are streams in conifer forest with a riparian buffer strip of 5-20 m width cleared 1-7 years previously and left to natural regeneration; BUF are streams in conifer forest with moorland/grassland buffer strips left at time of establishment; BRD are streams in conifer forest with buffer strips of deciduous trees and shrubs left at time of establishment; SNW are streams draining semi-natural broadleaf woodland; and MOR are streams draining moorland catchments. 
dense vegetation and have been reported to use young conifer plantations (Mason and Macdonald, 1986). Water voles prefer well-vegetated stream banks with suitable burrow sites safe above winter flood levels and open areas of tall tussocky herbaceous vegetation (Strachan, 1997). Open ground is also valuable as good quality deer pasture and access for larger bird species. For example, waterfowl need flight paths of 50-150 $\mathrm{m}$ to access the water surface (FC, 1990). The riparian woodland should be connected with other areas of semi-natural vegetation to create a network of wildlife corridors through the forest.

The riparian buffer is an important component of the local landscape and therefore its structure needs to be carefully designed and managed to be aesthetically pleasing. In particular, it can help to accentuate the pathway of a watercourse and so visually enhance the natural landform. The FC Forest Landscape Design Guidelines recommend that the mass of a forest should occasionally cross the stream to create an interesting mix of open space and broadleaf woodland. This is preferable to leaving a narrow piece of open ground on either side of a stream that can appear geometric and artificial (FC, 1994a).

Natural riparian vegetation is both spatially and temporally diverse. Nierenberg and Hibbs (2000) surveyed the riparian zone in unmanaged forests of coastal Oregon, USA and found that the vegetation was in a continual state of regeneration following local disturbances such as wildfire. After rapid initial colonisation of the exposed ground by pioneer species such as salmonberry and red alder, there was a much slower succession by other hardwoods and conifers. As the red alder declined naturally (100-150 years) localised disturbances caused by wind throw, landslides, hydraulic scouring and beavers exposed the mineral seedbed, enabling shade-intolerant species such as Douglas fir to become established. The authors estimated that such late-succession disturbances were very rare $(\approx 3$ per $100 \mathrm{~km}$ of stream per century) within this natural ecosystem.

\section{Species choice}

Most management guidelines recommend planting native woodland species in riparian buffers (Maitland et al., 1990; FC, 2003). Many in the UK refer to the National Vegetation Classification (NVC) system developed by Rodwell (1991) as an appropriate guide to species selection (FC, 1994c; MacKenzie, 1996; UK Biodiversity Group, 1998). The NVC is a systematic account of the natural, semi-natural and important artificial vegetation communities of Great Britain. Several of the plant communities identified in this scheme could be classed as riparian woodland when they are near freshwater (MacKenzie, 1996). Details of the distribution, species mix and soil type of seven woodland plant communities that are found naturally on permanently wet or poorly drained soils and classed as wet woodland are summarised in Table 5 (FC, 1994c). The FC has developed an Ecological Site Classification, based on climate, soil characteristics, and herbaceous indicator species, to assist forest managers in determining which NVC woodland would occur naturally at a particular site (Pyatt and Suárez, 1997).

Species choice affects the ability of the buffer to retain sediments and help control erosion through influencing the amount of shade. Tree and shrub species vary greatly in terms of canopy density and thus the level of shade cast. Riparian buffers are a more effective barrier to sediment transport when there is a vigorous herbaceous ground flora (Swift and Norton, 1993). Consequently, heavily shading species such as alder and oak should not be planted in large blocks but interspersed with lighter foliaged species like birch, willow, rowan, ash, hazel, aspen and bird cherry (FC, 2003). It also follows that species choice has an important role to play in regulating water temperature. In colder climates, light-foliaged species are generally favoured to provide dappled shade over the water surface and stream banks (Dobson et al., 1995).

Many authors report that the coniferous afforestation of the British uplands has had a detrimental effect on freshwater ecology and fisheries (Smith, 1980; Ormerod et al., 1986, 1989; Gee and Stoner, 1989; Maitland et al., 1990; O'Halloran and Giller, 1993). This has been ascribed mainly to the ability of conifers to enhance the acidification of basepoor upland streams due to the capture or scavenging of acid deposition (Ormerod et al., 1989; Gee and Stoner, 1989). Riparian stands were once thought to make a strong contribution to this process by the direct transfer of acid pollutants from forest canopy to stream. However, the clearance of riparian conifer crops has been shown to have a minimal effect on stream water acidification (Edwards et al., 1990). The lack of response is thought to reflect the relatively small proportion of forest canopy removed in relation to the whole catchment.

Riparian clearance treatments in non-acidified streams have also been found to have little effect on water chemistry, indicating that species choice in the riparian zone is a relatively unimportant factor in this regard (Morrison et al., 2002). One exception is the case of alder, due to its ability to fix atmospheric nitrogen and thus contribute to stream water acidification.

Native tree species add greatly to the overall biodiversity of conifer forests and are particularly valuable when planted within the riparian zone. This is because riparian woodland can form an important refuge and conduit for the movement 


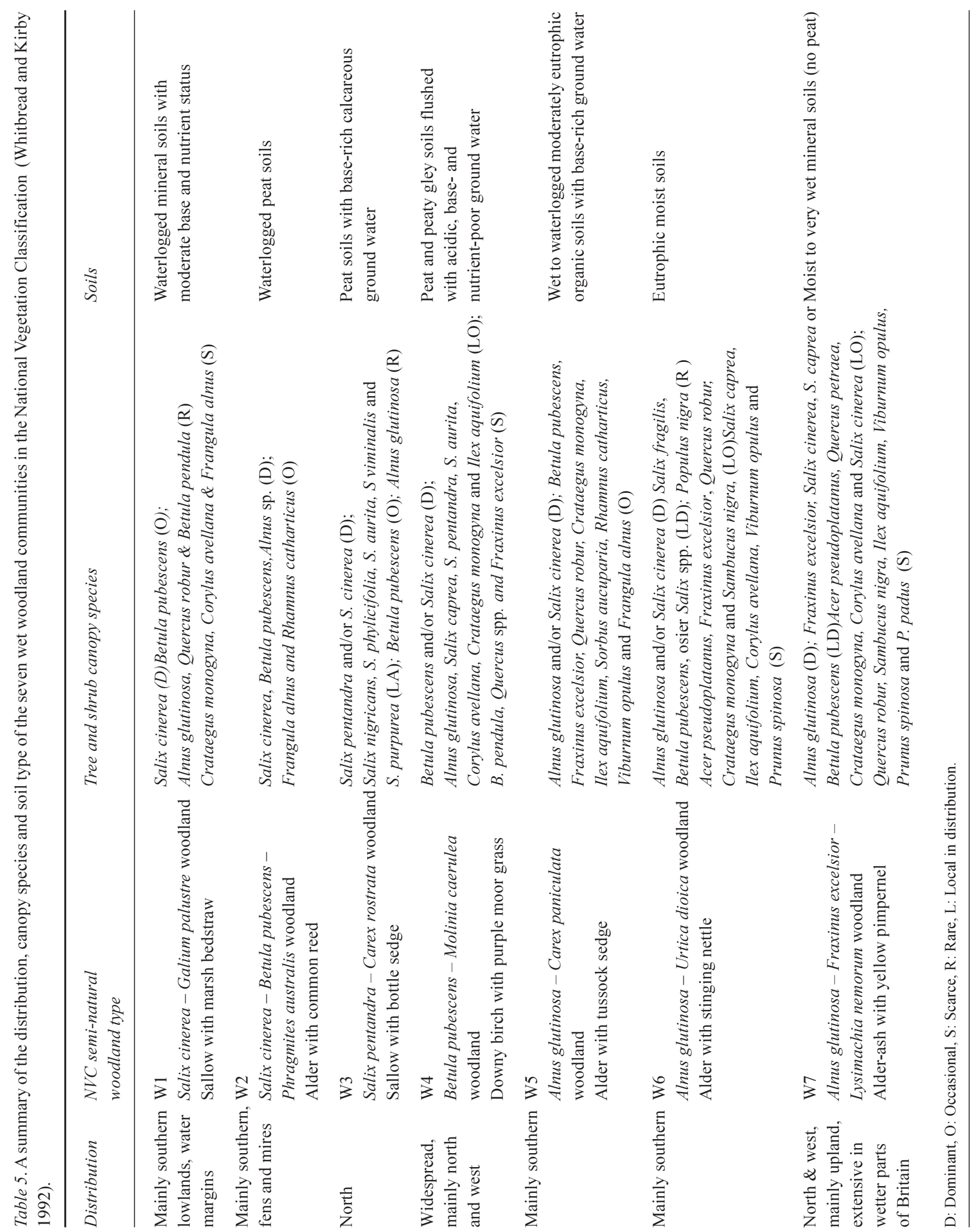


of many species throughout a catchment. For example, Wormell (1977) reported the rapid colonisation of restored woodland on the Isle of Rhum in Scotland by native flora and invertebrate fauna dispersing from relic fragments of riparian woodland. Native oak and willow species support the greatest diversity of lichen and invertebrate species, although birch is also very valuable, particularly in the north of Britain (FC, 1994c). Willow, birch and cherry provide good foraging habitat for bats because of the high biomass of terrestrial invertebrates that they support (Mayle, 1990). Terrestrial invertebrates are also an important component of the diet of salmonid fish (MacKenzie, 1996). The input of terrestrial insects into the Upper Tywi catchment in Wales was four times greater from riparian native broadleaves compared with conifers (Ormerod et al., 1986).

Alder is a riparian specialist and commonly found along middle and low-order streams in Scotland (MacKenzie, 1996; Maitland et al., 1990; FC, 2003). It is a deep-rooted species, capable of rapid early growth and tolerant of grazing. Historically it was often planted to stabilise riverbanks (SNW, 1996), although it has the disadvantage of quickly forming a dense canopy casting heavy shade over adjacent watercourses. Other problems include concern over its possible contribution to acidification and the recently reported widespread decline in tree health. A Phytophthora disease has become increasingly common in southern Britain, while in the north many alder trees suffer from crown thinning and branch dieback of an unknown cause. Alder has been virtually wiped out along significant stretches of riverbank in some Highland glens (Gregory et al., 1996). The FC recommends avoiding the planting of alder within riparian areas, especially in remote parts that are currently free from the disease (Gibbs and Lonsdale, 2000).

Scots pine is another valuable component of riparian woodland, especially in the central and western Highlands of Scotland where it is the natural forest climax community (FC, 1990). A reliable and significant cone crop supports a number of uncommon and rare birds and mammals, some of them not found elsewhere (FC, 1994b). Natural regeneration and planting should be encouraged, providing the development of dense stands is avoided. Exotic conifers such as larch, lodgepole pine and Norway spruce can also form valuable riparian woodland when they have reached maturity as open stands with a diverse and vigorous herbaceous ground cover. These should be retained at sites that are not at risk from high winds.

Many authors have reported that broadleaf trees and shrubs in the riparian zone enhance aquatic biodiversity compared to other vegetation types. The aquatic invertebrate biomass of 18 streams in the catchment of the River Tywi in Wales was found to reflect the quality of the allochthonous input to the water thus: broadleaf woodland $>$ circumneutral moorland $>$ conifer forest $=$ acidic moorland (Ormerod $e t$ al., 1986). Cowan (1998) found that a riparian zone of birch scrub and herbaceous moorland vegetation supported a more abundant and diverse stream macro invertebrate community than open moorland. The fall of leaf litter into headwater streams is an important energy input to the ecosystem (MacKenzie, 1996), with the quantity of litter reducing in the order: deciduous trees $>$ shrub $>$ herbaceous-shrub mix $>$ herbaceous (Delong and Brusven, 1994).

Moorland streams often lack impediments to stream flow so that leaf litter retention times are short. Dobson et al., (1995) showed that the invertebrate fauna of two circumneutral moorland streams in Wales were resource limited. They installed litter traps within the streams and then supplemented the naturally occurring detritus by adding mixed broadleaf leaf litter. The abundance of detritivore and predator invertebrate species subsequently increased, although the authors suggest that empty traps alone would have caused an increase in invertebrate biomass by retaining naturally occurring litter. Retention of leaf litter within conifer forests can also be inadequate due to the lack of large woody debris dams; regular thinning and the felling of the crop before maturity limits the supply of such material.

Aquatic invertebrates prefer feeding on broadleaf litter than on conifer needles (Ormerod et al., 1986). Collen (1994) reported that the rate of decay of leaf litter varied between native species in the order: bird cherry $>$ wych elm $>$ common alder $>$ silver birch $>$ goat willow $>$ sessile oak $>$ common beech. The cherry leaf had almost completely disappeared after 30 days whereas $40 \%$ of the oak leaf mass remained four months after being placed in the stream. Planting a mixture of broadleaf species will therefore extend the time that food material is available to stream detritivores.

The clearance of conifer stands from riparian zones has been shown to benefit benthic invertebrate and trout populations in forest streams where water quality is not a limiting factor. For example, the brown trout population of the Corrie Burn in central Scotland increased by $50 \%$ in the year after the crop was felled, with smaller increases in subsequent years (FFL, 1990). Similarly, the brown trout population of the Kirk Burn in southern Scotland increased after the riparian buffer was felled and partially replanted with broadleaf trees (Campbell, 2002).

These results suggest that the continuing re-design of upland conifer forests, involving the opening-up of riparian areas and the planting of native woodland, could aid the biological recolonisation of stream waters recovering from the effects of acid deposition.

Species choice can also enhance the visual quality of the landscape by providing a mix of textures and colour. This 
is particularly valuable in the context of the riparian zone by helping to mark out the course of a stream or river and so reinforce the landform. Native riparian woodland of mixed species is desirable as this best reflects the changing seasons and can be especially valuable in conifer plantations. The autumn colour is notable in many parts of the UK and is promoted by National Tourist Boards and the FC to encourage visitors into the countryside.

\section{Buffer management}

The riparian zone is an important transition between the aquatic zone and the adjacent land. In its natural state it has high biodiversity because of the mix of ecologically valuable edge habitats (MacKenzie, 1996; Patterson, 1989). These habitats are often depleted within afforested catchments due to changes in water chemistry (Collier and Winterbourn, 1989; Clenaghan et al., 1998; Ormerod et al., 1989), excessive shading (Ormerod et al., 1993; O'Grady, 1993; Reed et al., 1994), and the lack of age and structural diversity within tree stands (Morrison and Collen, 1991). Proactive management is therefore required so that the aquatic environment and water quality are protected and the value of the riparian habitat is enhanced (FC, 2003).

The FC first published guidance on stream side management in 1980. They recognised the need to protect fish populations in upland streams from the potentially damaging effects of forest management practices (Mills, 1980). This leaflet formed the basis of the first edition of the Forests and Water Guidelines (FC, 1988). The Guidelines set out the general principles and objectives of riparian management but are short on detail. This reflected the common preference for restoring native broadleaf woodland through natural regeneration and subsequent minimum intervention (Montgomery, 1997), and the problem of producing simple guidelines comprising general recommendations appropriate to all sites. Nevertheless, there is a clear role for management to achieve a sensible balance between the different functions of a riparian buffer, depending on site sensitivity and the needs of water users. Scope for conflict is probably greatest between fishery and conservation interests, which usually desire a different level of intervention.

In the USA, many State forestry agencies have published best management practices for riparian forests. Table 6 summarises the advice from 12 State forestry agencies for small perennial headwater streams. The silvicultural operations permitted within the riparian buffer differ from State to State. A number adopt a zonal approach, prohibiting all harvesting along the stream banks but allowing some harvesting beyond; others accept selective thinning up to the stream banks. Most States require some trees within the riparian zone to be retained, defined as either a percentage of canopy cover or basal area, and stress the importance of maintaining soil surface integrity to prevent erosion.

Management of the riparian buffer is necessary to maintain a vigorous cover of marginal and herbaceous vegetation for intercepting sediment and protecting stream banks from erosion. It is important to avoid excessive shading through careful design in terms of species choice and tree spacing in new planting schemes, and by the selective felling or coppicing of established sites. Obviously, a buffer will only be effective at retaining sediment if any drains terminate before the buffer and allow water to dissipate across it. This can be a problem on restock sites where the existing drains often discharge directly into streams. Where possible, drains should be blocked off and the system redesigned to create an intact buffer.

If cultivation is required to establish new riparian woodland it is important to minimise the extent of soil disturbance. Hinge mounding is the preferred technique, using the full reach of an excavator to avoid trafficking within the buffer. Very wet ground is best mounded by hand where practicable or left unplanted. Tree guards or shelters can be used to protect young saplings from grazing but fencing is required where the deer population is high or livestock have access to the riverbank. Fences need to be erected outside of the main flood channel so that they do not accumulate debris during spate flows (Mills, 1980).

The riparian and aquatic zones are very vulnerable to disturbance by forest machinery. The risk of serious erosion and siltation is greatest during timber extraction associated with thinning and harvesting operations. It is important to minimise trafficking of all machinery in the riparian zone and to make use of the full reach of harvesting equipment. Baillie et al., (1999) showed that extraction of timber along the riparian zone increased the load of fine woody debris in the stream channel, damaged bank sides and initiated soil erosion. At sites of high conservation value, timber extraction by horse should be considered (FC, 1998). If silt traps are required to control sediment losses from the adjacent land, access is required for periodic emptying. Spoil and brash must be deposited outside the riparian buffer to prevent these materials being washed into streams during flood conditions and causing blockages. Stable dams formed by large woody debris are beneficial to the freshwater environment and should be retained unless they become sealed by sediment and form a complete barrier to fish movement.

Active management is also required to sustain the ability of a riparian buffer to retain pollutants draining from the adjacent land. This is most relevant for riparian woodland 
Table 6. Examples of guidelines on setting riparian management zone widths and restrictions on harvesting for small perennial streams in twelve North American States (Adapted from Phillips et al. 2000).

\begin{tabular}{|c|c|c|c|c|}
\hline State & Water body & Width (m) & Specification & Harvest restrictions \\
\hline $\begin{array}{l}\text { Maryland } \\
1992\end{array}$ & $\begin{array}{l}\text { Perennial streams } \\
\text { and wetlands }\end{array}$ & $15-76$ & Depending on $\%$ slope & Maintain $14 \mathrm{~m}^{2}$ basal area $(\mathrm{BA}) \mathrm{ha}^{-1}$, even distribution \\
\hline $\begin{array}{l}\text { North Carolina } \\
1998\end{array}$ & $\begin{array}{l}\text { a Perennial streams } \\
\text { Critical areas }\end{array}$ & $\begin{array}{l}15-76 \\
23-91\end{array}$ & Depending on $\%$ slope & $\begin{array}{l}\text { Selective harvest of up to } 25 \% \text { of existing canopy, } \\
\text { creating }<21 \% \text { bare ground }\end{array}$ \\
\hline $\begin{array}{l}\text { New Jersey } \\
1995\end{array}$ & Open water and streams & $8-50$ & $\begin{array}{l}\text { Depending on \% slope } \\
\text { and soil erosion hazard }\end{array}$ & $\begin{array}{l}\text { No restriction on harvest system as long as } \\
\text { integrity of soil surface is maintained }\end{array}$ \\
\hline $\begin{array}{l}\text { Pennsylvania } \\
1993\end{array}$ & Streams & $15-50$ & $\begin{array}{l}\text { Increase by } 6 \mathrm{~m} \text { for each } \\
10 \% \text { increase in slope }\end{array}$ & $\begin{array}{l}\text { Remove }<50 \% \text { canopy, no harvest within } 3 \mathrm{~m} \text { of } \\
\text { the stream bank, minimise forest floor disturbance }\end{array}$ \\
\hline $\begin{array}{l}\text { Vermont } \\
1987\end{array}$ & $\begin{array}{l}<3 \mathrm{~m} \text { wide } \\
>3 \mathrm{~m} \text { wide }\end{array}$ & $\begin{array}{l}8 \\
15\end{array}$ & $\begin{array}{l}\text { Increase by } 6 \mathrm{~m} \text { for each } \\
10 \% \text { increase in slope } \\
\text { Increase by } 6 \mathrm{~m} \text { for each } \\
10 \% \text { increase in slope }\end{array}$ & $\begin{array}{l}\text { Light thinning or selective harvest, maintain shade } \\
\text { and stream bank stability }\end{array}$ \\
\hline $\begin{array}{l}\text { Ohio } \\
1992\end{array}$ & Perennial streams & 8 & & No harvest \\
\hline $\begin{array}{l}\text { Florida } \\
1993\end{array}$ & Perennial streams & $11-61$ & $\begin{array}{l}\text { Depending on the size of } \\
\text { water body, slope and soil } \\
\text { erodibility }\end{array}$ & Selective harvest, maintain integrity of soil surface \\
\hline $\begin{array}{l}\text { Minnesota } \\
1999\end{array}$ & Trout streams & $15-46$ & Depending on \% slope & $\begin{array}{l}\text { Shade tolerant species, retain } \\
6-18 \mathrm{~m}^{2} \mathrm{BA} \mathrm{ha}^{-1} \\
\text { Shade intolerant species, retain } \\
6 \mathrm{~m}^{2} \mathrm{BA} \mathrm{ha}^{-1} \\
\text { Shade tolerant species, retain } 14-18 \mathrm{~m}^{2} \mathrm{BA} \mathrm{ha}{ }^{-1}\end{array}$ \\
\hline $\begin{array}{l}\text { Tennessee } \\
1996\end{array}$ & Streams & 8 & $\begin{array}{l}\text { Increase by } 6 \mathrm{~m} \text { for each } \\
10 \% \text { increase in slope }\end{array}$ & $\begin{array}{l}\text { Remove } 25-50 \% \text { of canopy, minimize forest } \\
\text { floor disturbance }\end{array}$ \\
\hline $\begin{array}{l}\text { Maine } \\
1988\end{array}$ & $\begin{array}{l}1^{\text {st }}, 2^{\text {nd }} \& 3^{\text {rd }} \text { order } \\
\text { streams }\end{array}$ & 101 & $<20$ drains ha ${ }^{-1}$ & $\begin{array}{l}\text { No harvest within } 6 \mathrm{~m} \text { of stream bank } \\
\text { Selective harvest, }<40 \% \text { of volume and }<15 \mathrm{~cm} \\
\text { diameter at breast height in } 10 \text { years } \\
\text { No harvest within } 30 \mathrm{~m} \text { of stream bank }\end{array}$ \\
\hline $\begin{array}{l}\text { White } \\
\text { Mountain } \\
\text { National } \\
\text { Forest } \\
1986\end{array}$ & $\begin{array}{l}1^{\text {st }} \text { order streams, } \\
\text { in v-shaped valleys } \\
2^{\text {nd }} \text { order streams, } \\
\text { in flat-floored valleys }\end{array}$ & 15 & $\begin{array}{l}+(4 \times \text { slope gradient as } \%) \\
+(2 \times \text { slope gradient as } \%)\end{array}$ & Maintain shade and stream bank stability \\
\hline $\begin{array}{l}\text { New } \\
\text { Hampshire } \\
1996\end{array}$ & $\begin{array}{l}1^{\text {st }}, 2^{\text {nd }} \& 3^{\text {rd }} \text { order } \\
\text { streams }\end{array}$ & $\begin{array}{l}15 \\
91\end{array}$ & $\begin{array}{l}\text { Law } \\
\text { Voluntary code }\end{array}$ & $\begin{array}{l}<50 \% \text { of BA } \\
\text { No harvest within } 8 \mathrm{~m} \text { of stream banks }\end{array}$ \\
\hline
\end{tabular}

bordering agricultural land but is also an issue in forests subject to large-scale fertiliser and harvesting operations. Since pollutant retention is greatest for faster growing, early to middle aged successional woodland communities, a programme of regular coppicing will help to maintain a high demand for nutrients and prevent saturation. The USDA 
Forest Service has published a specification on the Internet for renovating or establishing new riparian forest buffers in open agricultural land to protect groundwater and surface water quality (Welsh, 1991).

The riparian buffer must not be used to store equipment, fuel oil or chemicals due to the high risk of leakage polluting adjacent watercourses. Brash needs to be removed from the buffer to promote revegetation, minimise the leaching of nutrients and prevent small woody debris from being washed into the stream (Fahey et al., 1991).

Establishing new riparian woodland through natural regeneration rather than planting has a lower potential impact on stream water quality, as no cultivation, fertilisation or weed control is usually required. Where planting is necessary, great care must be taken when applying fertiliser or pesticides near to watercourses. Applications should be limited to spot treatments and any pesticides used approved for use in or near water.

In general, management of the riparian buffer should look to create and maintain an open woodland canopy with around half the length of a watercourse open to sunlight. This will require close attention to species choice and riparian design, avoiding over stocking and excessive use of trees that cast heavy shade. Invasive weed species, such as rhododendron, and the natural regeneration of exotic conifers need to be controlled by cutting or spraying with herbicides, preferably before substantial areas are colonised (Low, 1985).

In time, willow and alder scrub may become too dense, casting undesirable heavy shade over watercourses. Coppicing is a traditional silvicultural method of managing riparian woodland and can create a diverse canopy of high wildlife value. Willow should be coppiced in a 20-25 year rotation and alder in a 10-20 year rotation where grazing is not a problem (FC, 1994c). High (>25 cm) coppice stools will help to protect the re-growth from floods and can become an important habitat for many moss and liverwort species. Pollarding is another traditional technique but requires skill and is therefore expensive. It will probably be suitable only for key sites with either a history of pollard management or high grazing pressure. An alternative to coppice management is to open up areas of dense scrub by selective thinning. There may also be a need to thin mature native riparian woodland where there is too much shade, depending on the management objectives for a given site and consideration of local fishery and conservation values. Where access is restricted, trees may have to be felled manually by chain saw and left in situ.

Grazing can be used to control woodland regeneration and shade on some sites with good access but it requires careful management and fencing. Fencing may cause problems for flood control and too many animals close to a watercourse can introduce pathogens such as cryptosporidium into water supplies.

Restrictions on access and the use of machinery in the riparian zone mean that management costs are likely to be high and, therefore, the control of shade may not be practical at all sites. Decisions should be based on riparian surveys and early consultation with the water regulatory authority, conservation agency and fishery groups to identify areas of high value or potential that would benefit from active management.

MacKenzie (1996) recommends that riparian buffers within conifer forests should resemble natural riparian woodland. Establishing native woodland is best achieved through natural regeneration where there is an appropriate seed source (Mills, 1980; FC, 1990; Maitland et al., 1990; FC, 1994). Any native trees or shrubs surviving from the first rotation are especially valuable for this purpose and should be protected from harvesting operations. Light tree seeds, such as birch and willow, will be carried for hundreds of metres by the wind, whereas heavier seeds, such as ash, will travel only tens of metres (Harmer and Kerr, 1995). Birch, alder and willow all produce large quantities of viable seed in most years and quickly colonise recently disturbed damp ground. Acceptable regeneration is possible when there are 20-30 parent trees per hectare (Evans, 1988; FC, 1994c).

Natural regeneration may also be suitable for establishing native conifer species if a mature cone-bearing tree of appropriate provenance is present. Scots pine produces seed in significant quantities every $2-4$ years with seed dispersal over 60-100 m. Trees will readily become established in pockets of open, well drained mineral soil, such as on raised knolls (Nixon and Worrell, 1999).

Planting will be necessary where there are no suitable seed sources or the ground vegetation is too vigorous to allow successful germination. Slow growing species such as oak benefit from the use of tree shelters. Trees should not be planted in areas of valuable or rare wetland herbaceous vegetation, including seepages, springs, marshes and small pools (Kirby, 1992). Planting stock should be native and preferably of local origin (FC, 1990; FC, 1994b).

Many authors report a considerable delay before cleared stream banks within conifer crops become ecologically effective riparian buffers (Rundle et al., 1992; Ormerod et al., 1993). Up to five years after the banks were cleared (10 $-50 \mathrm{~m}$ ), two streams of the Tywi catchment in Wales were not colonised by the Cordulegaster dragonfly, despite the water quality being physiochemically suitable for their survival and the absence of fish predation. (Ormerod et al., 1990). The new buffers lacked suitable larvae habitat such 
as accumulations of organic detritus, soft undercut banks and submerged Juncus and Molinia vegetation.

Active management and time are required to create and maintain the desired structural diversity within riparian woodlands. Old trees are important and especially valuable for supplying coarse woody debris to streams. In the natural forests of Canada, Russia and Poland, $60 \%$ of the trees and shrubs are dead or dying (Badenoch, 1997). Since it will take many years to establish such conditions, some authors advocate artificially adding coarse woody debris to enhance aquatic habitats. For example, Morrison and Collen (1991) used felled timber to create small weirs and deflectors within uniform sections of the Black Burn in Scotland. The structures created a series of deep pools and riffles, which improved trout habitat; the fry population increased tenfold in a single season. Keim et al. (1999) replicated the natural effects of wind blow in Oregon, USA by pulling mature alder trees across a stream. The fallen trees formed effective dams by trapping naturally occurring woody debris, although these began to lose their structural integrity after three years due to a rapid rate of decay. On wind firm sites where there is no native woodland, it may be desirable to retain a few conifer trees from the first rotation to provide some shade and coarse woody debris until the new riparian woodland becomes established (FE, 2002). However, these trees will also supply seed and any regeneration will need to be controlled.

Large woody debris is a cause for concern in flood prone areas where blocked bridges and culverts can contribute to flooding. In other locations, debris dams can restrict the passage of migrating fish. It is therefore important to manage in-channel woody debris where there is a risk to other water users. Linsted and Gurnell (1998) reviewed the role of large woody debris in Britain and produced a number of management recommendations, which are summarised in Fig. 4. They suggest that little management is generally needed in headwater streams less than $1.0 \mathrm{~m}$ wide, since the benefits of woody debris greatly outweigh any threats in such small streams. Debris dams become a barrier to fish mainly when they are filled with sediment or sealed by fine woody debris. When this happens, clearing the blockage is ecologically preferable to the removal of the entire dam. Brash from harvesting sites is a common cause of dams becoming impassable and needs to be kept out of the riparian zone and stored beyond the area at risk from seasonal flooding (Linsted and Gurnell, 1998). Large woody debris should be removed from flood risk areas, where practicable.

The UK has 2.7 million hectares of productive woodland, of which 1.6 million hectares is conifer forest (FC, 2002). Many thousands of kilometres of riverbank and freshwaters are enclosed within conifer crops, offering considerable scope for establishing native riparian woodlands and improving landscape quality. Felling and replanting create significant changes in forest appearance and need to be carefully planned to maximise the potential benefit in terms of the scale, diversity and unity of the wider landscape. Attention is required to avoid creating a uniform corridor or a geometric patchwork. Steep slopes with numerous small streams present a special problem and it may not be possible or desirable to leave buffers in such cases.

\begin{tabular}{|c|c|c|c|c|c|c|}
\hline Land Use & $\begin{array}{c}\text { Natural } \\
\text { Woodland }\end{array}$ & $\begin{array}{c}\text { Semi- } \\
\text { Natural } \\
\text { Woodland }\end{array}$ & $\begin{array}{l}\text { Plantation } \\
\text { Forestry }\end{array}$ & $\begin{array}{l}\text { Mixed Rural } \\
\text { Land Use }\end{array}$ & $\begin{array}{l}\text { Suburban } \\
\text { Land Use }\end{array}$ & Urban Areas \\
\hline Risk & \multicolumn{6}{|c|}{ Increasing economic cost of flooding $\rightarrow$} \\
\hline \multirow{5}{*}{$\begin{array}{l}\text { In-channel } \\
\text { management }\end{array}$} & \multicolumn{2}{|c|}{ No management } & \multicolumn{2}{|c|}{ Consider LWD addition } & & \\
\hline & & & \multicolumn{3}{|c|}{ Selectively remove LWD } & \\
\hline & & & $\begin{array}{l}\text { Of brash } \\
\text { from forestry } \\
\text { operations }\end{array}$ & \multicolumn{2}{|c|}{$\begin{array}{l}\text { Where necessary to } \\
\text { increase conveyance }\end{array}$} & \\
\hline & & & & & \multicolumn{2}{|c|}{ Completely remove LWD } \\
\hline & & & & & $\begin{array}{c}\text { Where } \\
\text { necessary to } \\
\text { increase } \\
\text { conveyance }\end{array}$ & $\begin{array}{l}\text { In most } \\
\text { locations }\end{array}$ \\
\hline \multirow{2}{*}{$\begin{array}{l}\text { Riparian zone } \\
\text { management }\end{array}$} & \multicolumn{2}{|c|}{ No management } & $\begin{array}{c}\text { Leave } \\
\text { woodland } \\
\text { buffer zone }\end{array}$ & & & \\
\hline & & & \multicolumn{2}{|c|}{$\begin{array}{l}\text { Actively manage/enhance } \\
\text { woodland buffer zones, } \\
\text { including tree planting }\end{array}$} & \multicolumn{2}{|c|}{$\begin{array}{l}\text { Prune riparian trees to } \\
\text { reduce LWD supply }\end{array}$} \\
\hline
\end{tabular}

Fig. 4. Management guidelines for large woody debris (LWD) in British headwater rivers (from Linsted \& Gurnell (1998)). 
The FC is committed to including riparian buffer areas when restructuring all conifer forests, although it will take several decades to complete the process across the whole estate. The overall aim is to link-up existing patches of broadleaf woodland and open ground to form a continuous network of native riparian woodland. This process is aided by the development of a catchment inventory and management plan, similar to that being implemented for the River Cree in south west Scotland (Soutar, 2003). Targeting riparian conifer stands for premature felling will help to speed up the process of forest conversion.

\section{Conclusions}

The principal objective of a riparian buffer is to protect the aquatic zone from disturbance by forest operations on the adjacent land. However, the riparian zone is also a valuable wildlife habitat and corridor for linking other patches of broadleaf woodland and open areas within conifer forested catchments. Therefore, a management plan should be prepared that addresses the riparian zone across the entire forest or catchment, preferably with the input and cooperation of adjacent landowners and the water, conservation and fishery authorities. Since riparian management is a long-term undertaking the plan will ensure that there is continuity of work while enabling other stakeholders to comment on and influence the management objectives. Initially, the complete catchment should be surveyed to identify sensitive sites and areas of high value or potential for improvement. This will inform the planning process and allow the main functions of a site to be identified, e.g. protecting water quality, moderating shade and water temperature, maintaining ecological integrity or landscape improvement. It will then be possible to phase any future harvesting and restructuring work to gain maximum environmental benefit.

The width of buffer should reflect the natural dimensions of the aquatic and riparian zones. It is not possible to specify a definitive minimum buffer width that will ensure the protection of all freshwater environments from every potential threat, although widths in the range of 5-30m have been found to provide at least $50 \%$ and often $75 \%$ or greater effectiveness at preserving the various functions associated with undisturbed forest streams. In general, the aim should be to establish and maintain an open woodland canopy to leave about half the watercourse open to sunlight, with the remainder being under dappled shade. This is best achieved by creating a mosaic of five vegetation structural habitats: open ground; occasional large trees; trees with open glades; scrub thicket; and closed woodland canopy. Shade levels should allow the development of an essentially continuous cover of herbaceous ground and marginal vegetation. Riparian woodland should preferably be established by natural regeneration and be native and appropriate to the location and soil water regime.

\section{Acknowledgements}

This review was funded by the Scotland and Northern Ireland Forum for Environmental Research (SR (02) 06).

\section{References}

Badenoch, C., 1997. Woodland origins and the loss of native woodland in the Tweed valley. Scottish Forestry, 51, 15-20.

Baillie, B.R., Cummins, T.I. and Kimberley, M.O., 1999. Harvesting effects on woody debris and bank disturbance in stream channels. NZ J. Forestry Sci., 29, 85-101.

Barlow, J.F. and Harrison, G., 1999. Shaded by trees - trees in focus practical care and management. Arboricultural Advisory and Information Service. ISSN 1358-8249.

Barton, D.R., Taylor, W.D. and Biette, R.M., 1985. Dimensions of riparian buffer strips required to maintain trout habitat in southern Ontario streams. NAmer. J. Fisheries Manage., 5, 364378.

Beschta, R.L., Bilby, R.E., Brown, G.W., Holtby, L.B. and Hofstra, T.D., 1987. Stream temperature and aquatic habitat: Fisheries and Forestry interactions In: Streamside management: forestry and fishery interactions. E.O. Salo and T.W. Cundy (Eds.) Institute of Forest Research, University of Washington, Seattle, WA, USA. 191-232.

Blinn, C.R. and Kilgore, M.A., 2001. Riparian Management Practices - A summary of State Guidelines. J. Forestry, 99, 1117.

Brazier, J.R. and Brown, G.W., 1973. Buffer strips for stream temperature control. Research Paper 15. Forest Research Lab., Oregon State Univ., Corvallis, OR, USA.

Bren, L.J., 1995. Aspects of the geometry of riparian buffer strips and its significance to forestry operations. Forest Ecol. Manage., 75, 1-10.

Broderson, J.M., 1973. Sizing buffer strips to maintain water quality. MS thesis. Univ. of Washington, Seattle, WA, USA.

Campbell, R., 2002. The Kirk Burn Study 1990 - 1993 and 2001. In: The effect of riparian forest management on the freshwater environment. Final Report to the Scotland \& Northern Ireland Forum for Environmental Research (SNIFFER) under contract SR(02)06. Foundation for Water Research, Marlow, UK.

Castelle, A.J. and Johnson, A.W., 2000. Riparian vegetation effectiveness. Technical Bulletin No. 799. National Council for Air and Stream Improvement, Research Triangle Park, NC, USA.

Castelle, A.J., Johnson, A.W. and Conolly, C., 1994. Wetland and stream buffer size requirements - A review. J. Environ. Qual., 23, 878-882.

Centre for Ecology and Hydrology, 2001, http:// critlaods.ceh.ac.uk.

Clenaghan, C., Giller, P.S., O’Halloran, H. and Hernan, R., 1998. Stream macro-invertebrate communities in a conifer-afforested catchment in Ireland: Relationships to physio-chemical and biotic factors. Freshwater Biol., 40, 175-193.

Collen, P., 1994. The influence of riparian tree selection on stream invertebrate production. Scot. Forestry, 48, 262-270. 
Collier, K.J. and Winterbourn, M.J., 1989. Impacts of wetland afforestation on the distribution of benthic invertebrates in acid streams of Westland, New Zealand. NZJ. Mar. Freshwater Res., 23, 479-490.

Cowan, D., 1998. Mitigation of headwater acidification in forests by use of unplanted riparian zones: a study in northern England. In: Headwaters: water resources and soil conservation. Proceedings of headwater ' $98,4^{\text {th }}$ International conference on Headwater Control, Merano, Italy. 159-166.

Crisp, D.T., 1996. Environmental requirements of common riverine European Salmonid fish species in freshwater with particular reference to physical and chemical aspects. Hydrobiologia, 323, 201-221.

Curry, R.A., Scruton, D.A. and Clarke, K.D., 2002. The thermal regimes of brook trout incubation habitats and evidence of changes during forestry operations. Can. J. Forest. Res., 32, $1200-1207$.

Delong, M.D. and Brusven, M.A., 1994. Allochthonous input of organic matter from riparian habitats of an agricultural impacted stream. Environ. Manage., 18, 59--71.

Dobson, M., Hildrew, A.G., Orton, S. and Ormerod, S.J., 1995. Increasing litter retention in moorland streams: ecological and management aspects of a field experiment. Freshwater Biol., 33, 325-337.

Edwards, R.W., Stoner, J.H. and Gee, A.P., 1990. Acid Waters in Wales. Kluwer, Dordrecht, The Netherlands.

Erman, D.C., Newbold, J.D. and Roby, K.B., 1977. Evaluation of streamside bufferstrips for protecting aquatic organisms. Technical Completion Report, California Water Resource Centre, University of California-Davis, Davis, CA, USA.

Evans, J., 1988. Natural regeneration of broadleaves. Bulletin 78, Forestry Commission, UK.

Fahey, T.J., Hill, M.O., Stevens, P.A., Hornung, M. and Rowland, P., 1991. Nutrient accumulation in vegetation following conventional and whole-tree harvest of Sitka Spruce plantations in north Wales. Forestry, 64, 271-288.

Florida Department of Agriculture and Consumer Services, 1993. Silviculture best management practices, USA.

Forestry Commission, 1988. Forest and water guidelines. Forestry Commission, UK.

Forestry Commission, 1990. Forest nature conservation guidelines. Forestry Commission, UK.

Forestry Commission, 1994a. Forest landscape design guidelines. Forestry Commission, UK.

Forestry Commission, 1994b. The management of semi-natural woodlands: native pinewoods. Forestry Practice Guide 7, Forestry Commission. UK.

Forestry Commission, 1994c. The management of semi-natural woodlands: wet woodlands. Forestry Practice Guide 8, Forestry Commission, UK.

Forestry Commission, 1998. The UK forestry standard. The government's approach to sustainable forestry. Forestry Commission, UK.

Forestry Commission, 2000. Forest and water guidelines. Forestry Commission, UK.

Forestry Commission, 2002. Forestry facts and figures 2002. A summary of statistics about woodland and forestry in Great Britain. Forestry Commission, UK.

Forest Enterprise, 2002. Life in the Deadwood. A guide to managing deadwood in Forestry Commission forests. Forest Enterprise. UK.

Forest Service, 2000. Forestry and water quality guidelines. Forest Service, Department of the Marine and Natural Resources, Dublin, Ireland. 13pp.

Freshwater Fisheries Laboratory, 1990. Effects of forest shading on a Brown trout population. Freshwater Fisheries Laboratory, Pitlochry, UK. Annual Review 1989-1990.
Gee, A.S. and Stoner, J.H., 1989. A review of the causes and effects of acidification of surface waters in Wales and potential mitigation techniques. Arch. Environ. Contam. Toxicol., 18, 121130.

Gibbs, J. and Lonsdale, D., 2000. Phytophthora disease of Alder. Information Note FCIN6 (Revised), Forestry Commission, UK.

Glova, G.J. and Sagar, P.M., 1994. Comparison of fish and macro invertebrate standing stocks in relation to riparian willows (Salix spp.) in three New Zealand streams. NZ J. Mar. Freshwater Res., 28, 255-266.

Gregory, S., MacAskill, G. and Winter, T., 1996. Crown thinning and dieback of alder in northern Britain. Research Information Note 283, Forestry Commission, UK.

Harmer, R. and Kerr, G., 1995. Natural regeneration of broadleaved trees. Research Information Note 275, Forestry Commission, UK

Haycock, N.E. and Pinay, G., 1993. Groundwater nitrate dynamics in grass and poplar vegetated riparian buffer strips during the winter. J. Environ. Qual., 22, 273-278.

Haycock, N.E., Pinay, G., and Walker, C., 1993. Nitrogen retention in river corridors: European perspective. Ambio, 22, 340-346.

Hubbard, R.K. and Lowrance, R.R., 1994. Riparian forest buffer system research at the coastal plain experiment station, Water, Air Soil Pollut., 77, 409-432

Ilhardt, B.L., Verry, E.S., and Palik, B.J., 2000. Defining riparian areas. In Riparian management in forests of the continental eastern United States. E.S. Verry, J.W. Hornbeck and C.A. Dolloff (Eds.). Lewis, Washington, USA. 23-43.

Keim, R.F., Skaugset, A.E. and Bateman, D.S., 1999. Dynamics of coarse woody debris placed in three Oregon streams. Forest Sci., 46, 13-21.

Kirby, P., 1992. Habitat management for invertebrate: a practical handbook. Joint Nature Conservation Committee. RSPB, Sandy, Bedfordshire, UK. 150pp.

Lester, P.J., Mitchell, S.F. and Scott, D., 1994. Effects of riparian willow trees (Salix fragilis) on macro invertebrate densities in two small Central Otago, New Zealand, streams. NZ J. Mar. Freshwater Res., 28, 267-276.

Linsted, C. and Gurnell, A.M., 1998. Large woody debris in British headwater rivers. Physical habitat role and management guidelines. R \& D Technical Report W185, Environment Agency, UK.

Low, A.J., 1985. Guide to upland restocking practice. Leaflet 84, Forestry Commission, UK.

Lowrance, R., Leonard, R. and Sheridan, J., 1985. Managing riparian ecosystems to control non-point source pollution. $J$. Soil Water Conserv., 40, 87-91.

Lynch, J.A., Corbett, E.S. and Mussallem, K., 1985. Best management practices for controlling non-point source pollution on forested watersheds. J. Soil Water Conserv., 40, 164-167.

Mackenzie, N.A., 1996. The riparian woodland ecotone. Scottish Native Woods. Aberfeldy, Perthshire, UK. 55pp.

Maitland, P.S., Newson, M.D. and Best, G.A., 1990. The impacts of afforestation and forestry practice on freshwater habitats. Focus on Nature Conservation No. 23, Nature Conservancy Council, UK

Mason, C.F. and Macdonald, S.M., 1986. Otters: ecology and conservation. Cambridge University Press, UK.

Mayle, B.A., 1990. Habitat management for woodland bats. Research Information Note 165, Forestry Commission, UK.

Mel'chanov, V.A., 1988. Determination of the optimal width of water-treating forest belts along small rivers. All-Union Scientific-Research Institute of Silviculture and Mechanization of Forestry, 1, 157-161. Plenum Publishing Corporation, New York, NY, USA. 
Mills, D., 1980. The management of forest streams. Leaflet 78, Forestry Commission, UK

Montgomery, D.R., 1997. What's best on the banks? Nature, 388, 328-329.

Moring, J.R., 1982. Decrease in stream gravel permeability after clear-cut logging: an indication of intragravel conditions for developing salmonid eggs and alevins. Hydrobiologia, 88, 295298.

Morrison, R.S. and Collen, P., 1991. Stream habitat improvement for trout (Salmo trutta L.) in a clearfelled catchment in southwest Scotland. Scottish For, 46, 321-330.

Morrison, B.R.S., Keay, J., Bridcut, E.E., Collen, P. and Harriman, R. 2002. The effects of riparian management on benthic macro invertebrate communities at four sites on Burn 7 and the Corrie Burn in Loch Ard forest. In: The effect of riparian forest management on the freshwater environment. Final Report to the Scotland \& Northern Ireland Forum for Environmental Research (SNIFFER) under contract SR(02)06. Foundation for Water Research, Marlow, UK.

Nakamura, F. and Dokai, T., 1989. Estimation of the effect of riparian forest on stream temperature based on heat budget. $J$. Jpn. Forestry Soc., 71, 387-394

Neal, C. and Reynolds, B., 1998. The impact of conifer harvesting and replanting on upland water quality. $\mathrm{R} \& \mathrm{D}$ Technical Paper P211, Environment Agency, UK

Nierenberg, T.R. and Hibbs, D.E., 2000. A characterisation of unmanaged riparian areas in the central coast range of western Oregon. Forest Ecol. Manage., 129, 195-206.

Nixon, C.J. and Worrell, R., 1999. The potential for the natural regeneration of conifers in Britain. Bulletin 120, Forestry Commission, UK.

O'Connor, N.A., 1992. Quantification of submerged wood in a lowland Australian stream system. Freshwater Biol., 27, $387-$ 395.

O'Grady, M.F., 1993. Initial observations on the effects of varying levels of deciduous bank side vegetation on Salmonid stocks in Irish waters. Aquat. Fisheries Manage., 24, 563-573.

O'Halloran, J. and Giller, P.S., 1993. Forestry and the Ecology of streams and rivers: lessons from abroad? Irish Forestry, 50, 3552.

O'Laughlin, J. and Belt, G.H., 1995. Functional approaches to riparian buffer strip design. J. Forestry, 93, 29-32.

Oelbermann, M. and Gordon, A.M., 2000. Quantity and quality of autumnal litterfall into a rehabilitated agricultural stream. $J$. Environ. Qual., 29, 603-611.

Office National des Forêts, 1999. L'eau et la Foret. Bulletin technique No. 37. ONF, Department Researche et Développement, Service de documentation, Fountainebleau, France 232pp.

Ormerod, S.J. and Tyler, S.J, 1991. The influence of stream acidification and riparian land use on the feeding ecology of Grey Wagtails Motacilla cinerea in Wales. IBIS 133, 53-61.

Ormerod, S.J., Mawle G.W., and Edwards, R.W., 1986. The influence of forests on aquatic fauna. In: Environmental aspects of plantation forestry in Wales, J.E.G. Good (Ed.), Institute of Terrestrial Ecology Symposium No. 22, NERC, UK.

Ormerod, S.J., Donald, A.S., and Brown, S.J., 1989. The influence of plantation forestry on the $\mathrm{pH}$ and $\mathrm{Al}$ concentration of upland Welsh streams, a re-examination. Environ. Pollut., 62, 47-62.

Ormerod, S.J., Weatherley, N.S., and Merrett, W.J., 1990. The influence of conifer plantations on the distribution of the Golden Ringed dragonfly Cordulegaster boltoni (Odonata) in upland Wales. Biol. Conserv., 53, 241-251.

Ormerod, S.J., Rundle, S.D., Lloyd, E.C. and Douglas, A.A., 1993. The influence of riparian management on the habitat structure and macro invertebrate communities of upland streams draining plantation forests. J. Appl. Ecol., 30, 13-24.
Patterson, G.S., 1989. Management of Riparian Edges. Occasional Paper 28, 57-63, Forestry Commission, U.K.

Phillips, J.D., 1989. Nonpoint source pollution control effectiveness of riparian forests along a coastal plain river. $J$. Hydrol., 110, 221-237.

Phillips, M.J., Swift, L.W. and Blinn, C.R.., 2000. Best management practices for riparian areas. In: Riparian management in forests of the continental eastern United States. E.S. Verry, J.W. Hornbeck and C.A. Dolloff, (Eds.), Lewis publishers, UK.

Pinay, G., Roques, L. and Fabre, A., 1993. Spatial and temporal patterns of denitrification in a riparian forest. J. Appl. Ecol., 30, 581-591

Procter, J., 1986. Effects of acidification on algal epilithon. MSc thesis, University of Wales.

Pyatt, D.G. and Suárez, J.C., 1997. An ecological site classification for forestry in Great Britain. With special reference to Grampian, Scotland. Technical Paper 20, Forestry Commission, UK.

Quigley, T.M., 1981. Estimating contribution of overstory vegetation to stream surface shade. Wildife Society Bulletin, $\mathbf{9}$, No.1 .22-27.

Reed, J.L., Campbell, I.C. and Bailey, P.C.E., 1994. The relationship between invertebrate assemblages and available food at forest and pasture sites in three south-eastern Australian streams. Freshwater Biol., 32, 641-650.

Reynolds, B., Stevens, P.A., Hughes, S., Parkinson, J.A. and Weatherley, N.S., 1995. Stream chemistry impacts of conifer harvesting in Welsh catchments. Water Air Soil Pollut., 79, 147170.

Rodwell, J.S., 1991. British plant communities Volume 1: Woodlands and Scrub. Nature Conservancy Council, UK.

Rundle, S.D., Lloyd, E.C. and Ormerod, S.J., 1992. The effects of riparian management and physicochemistry on macro invertebrate feeding guilds and community structure in upland British streams. Aquat. Conserv., 2, 309-324.

Rutt, G.P., Weatherley, N.S. and Ormerod, S.J., 1989. Macrohabitat availability in Welsh moorland and forest streams as a determinant of macro invertebrate distribution. Freshwater Biol., 22, 247-261.

Scottish Native Woods, 1996. Why Manage Riparian Woodlands? Information and Guidance for Managers. Scottish Native Woods. Aberfeldy, Perthshire, UK. 30pp.

Skogsstyrelsen, 2000. Skogsbruk vid vatten. Rapport nr 5035. Skogsstyrelsen, Jönköping, Sweden. 28pp.

Smith, B.D., 1980. The effects of afforestation on the Trout of a small stream in southern Scotland. Fish Manage., 11, 39-58.

Soutar, R. 2003. Demonstration of sustainable forestry to protect water quality and aquatic biodiversity. Final report to EU for LIFE Project: LIFE99 ENV/UK/000182. European Union, Brussels.

Strachan, R., 1997. Water Voles. Whittet Books Ltd., London, UK. 96pp.

Sweeney, B.W., 1993. Effects of streamside vegetation on macro invertebrate communities of White Clay Creek in eastern north America. Proc. Acad. Natur. Sci. Phil., 144, 291-340.

Swift, D.W. and Norton, R.L., 1993. Measures for protecting upland water quality: assessment of forestry buffer strips. Final R\&D Report to the Scotland \& Northern Ireland Forum for Environmental Research (SNIFFER) under contract SR3442/ 1. SNIFFER, Edinburgh, UK.

UK Biodiversity Group, 1998. Tranche 2 Action Plans Volume II - terrestrial and freshwater habitats. English Nature. UK.

Weatherley, N.S. and Ormerod, S.J., 1990. Forests and the temperature of upland streams in Wales: a modelling exploration of the biological effects. Freshwater Biol., 24, 109-122. 
Weatherley, N.S., Rutt, G.P. and Ormerod, S.J., 1989. Densities of benthic macro invertebrates in upland Welsh streams of different acidity and land use. Archive Forest Hydrobiologie, 115, 417-431.

Weatherley, N.S., Lloyd, E.C., Rundle, S.D. and Ormerod, S.J., 1993. Management of conifer plantations for the conservation of stream macro invertebrates. Biol. Conserv., 63, 171-176.

Welsh, D., 1991. http:\www.na.fs.fed.us/spfo/pubs/n resource/ riparianforests Riparian Forest Buffers - Function and design for protection and enhancement of water resources. USDA-FS.

Whitbread, A.M. and Kirby, K.J., 1992. UK Nature Conservation No.4, Summary of national vegetation classification woodland descriptions. Joint Nature Conservation Committee, UK.

Wormell, P., 1977. Woodland insect population changes on the Isle of Rhum in relation to forest history and woodland restoration. Scot. Forestry, 31, 13-36.
Wong, S.L. and McCuen, R.H., 1982. The design of vegetative buffer strips for run-off and sediment control. A technical paper developed as part of a study of storm water management in coastal areas funded by Maryland coastal zone management program., University of Maryland, MD, USA.

Xu, L., Gilliam, J.W. and Daniels, R.B., 1992. Nitrate movement and loss in riparian buffer areas. In: Agronomy abstracts. ASA Madison, WI, USA.

Zwieniecki, M.A. and Newton, M., 1999. Influence of streamside cover and stream features on temperature trends in forested streams of western Oregon. West. J. Appl. Forestry, 14, 106113. 